\title{
Codec Citra Berbasis Fractal dan Entropy Coding
}

\author{
I Made Aditya Virgiawan ${ }^{1}$, I Made Oka Widyantara ${ }^{2}$, Rukmi Sari Hartati ${ }^{3}$ \\ Submission: 17-05-2019, Accepted: 22-08-2019
}

\begin{abstract}
The process of describing parts of the human body, to be able to find any disease that exists in the body parts caused by bacteria and viruses is called the Medical Image. CT Scanning, MRI, X-Ray, is a medical image that is commonly found in general in the form of analog data. The amount of important information contained in medical images causes the size of the medical image file to be relatively large. The need for large data storage media and long delivery times is caused by large medical image data. This study aims to realize a fractal-based medical image codec by testing its performance on several coding entropy techniques. The analysis of this study was based on the PSNR, Image Size and Time Taken needed to compress one image. The conclusion obtained from this analysis shows that the Arithmetic method has more advantages in the field of PSNR, Compression Ratio, Size Image produced along with Time Taken in the compression process, where 15 images of 100\% images are better results using the Arithmetic method than by using the Adaptive Huffman method.
\end{abstract}

Keyword- Adaptive Huffman, Arithmetic, Codec, Fractal, Image, Medical.

Intisari- Proses penggambaran bagian organ tubuh manusia, untuk dapat menemukan penyakit apa saja yang ada pada bagian tubuh yang disebabkan oleh bakteri dan virus disebut dengan Citra Medis. CT Scanning, MRI, X-Ray, merupakan citra medis yang banyak ditemui pada umumnya masih berupa data analog. Banyaknya informasi penting yang terdapat pada citra medis menyebabkan ukuran file citra medis tergolong besar. Kebutuhan media penyimpanan data yang besar dan waktu pengiriman yang lama disebabkan oleh data citra medis yang berukuran besar. Penelitian ini bertujuan untuk merealisasikan sebuah codec citra medis berbasis fraktal dengan mengujikan kinerjanya pada beberapa teknik entropy coding. Analisis penelitian ini didasarkan pada PSNR, Size Image dan Time Taken yang dibutuhkan untuk melakukan kompresi terhadap satu buah gambar. Kesimpulan yang didapat pada analisis ini terlihat bahwa metode Arithmetic lebih memiliki keunggulan dalam bidang PSNR, Rasio Kompresi, Size Image yang dihasilkan beserta Time Taken di dalam proses kompresi, dimana dari 15 gambar citra yang diuji $100 \%$ gambar lebih baik hasil dengan menggunakan metode Arithmetic dibandingkan dengan menggunakan metode Adaptive Huffman.

Kata Kunci- Adaptive Huffman, Arithmetic, Citra, Codec, Fractal, Medis.

\section{PENDAHULUAN}

Proses penggambaran bagian organ tubuh manusia, untuk

${ }^{1}$ Mahasiswa, Magister Teknik Elektro Universitas Udayana, Jl. P.B. Sudirman, Denpasar, Bali, 80114, (tlp: 0361-555225; fax: 0361-4321982; e-mail: ictbalicomputer@gmail.com)

2, 3 Dosen, MagisterTeknik Elektro dan Komputer Fakultas Teknik Universitas Udayana, Jln. Jalan Kampus Bukit Jimbaran 80361 INDONESIA (telp: 0361-703315; fax: 0361-4321; e-mail: mdokawidyantara@unud..ac.id),rukmisarihartati@unud.ac.id

I Made Aditya Virgiawan : Codec Citra Berbasis Fractal...... dapat menemukan penyakit apa saja yang ada pada bagian tubuh yang disebabkan oleh bakteri dan virus disebut dengan Citra Medis. PET (Positron Emission Tomography), CT (Computed Tomography) Scanning, USG (Ultrasonografi), MRI (Magnetic Resonance Imaging), X-Ray, merupakan citra medis yang banyak ditemui pada umumnya masih berupa data analog. Guna menghindari dari kerusakan, data citra medis yang masih berupa analog ini memerlukan tempat khusus atau suatu ruangan untuk penyimpanan. Mengacu pada standar DICOM, kini banyak citra medis yang sudah di digitalisasikan guna memenuhi standar keamanan untuk data citra medis tersebut.

Prosedur pengerjaan secara umum untuk mengarsip, mencetak, serta mengirimkan suatu informasi pada pencitraan medis disebut dengan (DICOM) Digital Imaging dan Communications in Medicine. (NEMA) The National Electrical Manufacturers Association sebagai badan pemilik hak cipta pada standar (DICOM). Standar DICOM menspesifikasikan suatu Information Object Definition (IOD) untuk memodelkan semua informasi yang terkait dengan proses pencitraan medis. Suatu entitas informasi, yaitu entitas pasien yang berisikan data pasien serta entitas studi yang berisikan data hasil informasi pemeriksaan dikandung pada Information Object Definition (IOD)[1].

Ukuran file citra medis tergolong besar disebabkan oleh banyaknya informasi penting yang terdapat pada citra medis. Besarnya kapasitas file citra medis disebabkan oleh resolusi scanning citra yang semakin meningkat juga, sehingga membutuhkan sumber daya yang cukup untuk menyimpan, mengolah, dan mengirimkan data citra medis apalagi jika ditransmisikan pada bandwidth yang sangat terbatas. Dibutuhkannya suatu teknik kompresi citra medis yang tidak mengurangi informasi yang terkandung didalam citra tersebut (lossless) yang disebabkan oleh citra medis karena pada umumnya suatu data citra masih berukuran besar yang dapat menyebabkan masalah dalam media penyimpanan serta proses pengiriman data citra medis tersebut.

Teknik untuk menghilangkan berbagai redundansi dari suatu informasi, tetapi tetap dapat menjaga kualitas penggambaran dari informasi tersebut disbut dengan kompresi. Terdapat dua teknik kompresi citra, yakni lossy compression dan lossless compression. Mengurangi ukuran data citra agar mendapatkan hasil kompresi citra yang sama dengan citra aslinya merupakan teknik kompresi lossless, sedangkan mereduksi ukuran data dengan menghilangkan beberapa informasi pada citra, tetapi dapat memberikan hasil visual yang mirip dengan citra asli merupakan teknik kompresi lossy [2].

Menghasilkan perbandingan kompresi yang lebih tinggi dengan kualitas dekompresi yang baik serta waktu dekompresi yang sangat cepat merupakan keuntungan yang diperoleh dengan menggunakan pemapatan citra fractal. Pemapatan p-ISSN:1693 - 2951; e-ISSN: 2503-2372 
citra fractal memiliki multiresolution, yaitu sebuah gambar dapat didekompresi pada tingkat resolusi yang lebih tinggi atau lebih rendah dari pada citra asli merupakan keuntungan lain dari kompresi pemapatan citra fractal [3]. Selain proses transformasi, kunci dari skema kompresi citra terdapat pada teknik entropy coding yang digunakan. Teknik pengkodean data yang menghasilkan representasi data baru yang kapasitas datanya lebih kecil tanpa menghilangkan informasi apapun disebut dengan teknik entropy coding.

Penelitian kompresi citra fractal menggunakan teknik entropy coding yang berjudul "Integrasi Kompresi Citra fractal Terhadap Kuantisasi Quadtree dan Entropy Coding" dihasilkan dengan cara mengintegrasikan kuantisasi Quadtree dan pengkodean entropi yang digunakan untuk kompresi citra fractal. Membagi kuantisasi gambar tingkat abu-abu asli ke dalam berbagai blok tergantung pada nilai ambang batas menggunakan metode quadtree kuantitatif, selain sifat dari fitur yang disajikan dalam gambar, pengkodean entropi diterapkan untuk memperbaiki kualitas kompresi. Hasil simulasi menunjukkan bahwa pengkodean quadtree dan entropi terkuantisasi dapat meningkatkan rasio kompresi dan kualitasnya yang berasal dari kompresi gambar fractal dengan jangkauan blok dan teknik iterasi [4].

Penelitian yang berjudul "Kompresi Citra Fractal menggunakan Quadtree Dekomposisi dan Pengkodean Huffman", menjelaskan proses kompresi gambar fractal dapat diperoleh dengan teknik dekomposisi Quadtree dan teknik pengkodean Huffman. Hasil simulasi matlab menunjukkan bahwa untuk pendekatan dekomposisi Quadtree menunjukkan perbaikan yang sangat signifikan pada rasio kompresi dan nilai PSNR yang berasal dari kompresi fractal dengan teknik blok dan iterasi jarak jauh. Hasil penelitian menunjukkan bahwa untuk citra Lena $\mathrm{C} R$ adalah nilai 2,02 dan PSNR adalah 29,92dB, citra satelit Pedesaan 3,08 dan 29,34dB, citra satelit perkotaan 5,99 dan $28,12 \mathrm{~dB}$. Untuk mencapai rasio kompresi yang tinggi dan nilai PSNR yang lebih baik pada citra satelit dapat diperoleh dengan menggunakan teknik fractal yang dikombinasikan dengan entropi kode huffman [5].

Penelitian yang berjudul "Algoritma Kompresi Digital Citra Medis Menggunakan Pengkodean Adaptive Huffman Berbasis Grafik Kuantisasi Berdasarkan IWT-SVD, menjelaskan kompresi gambar berdasarkan Integer Wavelet Transform (IWT) \& SVD, dengan menggunakan kuantisasi berbasis grafik, namun pengkodean entropi yang digunakan adalah pengkodean Adaptive Huffman. Selain itu, IWT digunakan dalam sistem ini karena bersifat reversibel. Sistem kompresi dirancang untuk menghasilkan nilai PSNR rata-rata di kisaran 50-53 dB dan rasio kompresi berkisar antara 7885\%. Teknik entropi koding Adaptive Huffman sangat baik dalam proses kompresi gambar dan juga menghasilkan kualitas citra yang baik [6]

Penelitian yang berjudul "Pengkodean Aritmatika Adaptif Yang Efisien Untuk Kompresi Gambar Lossless Berbasis Blok Menggunakan Model Campuran" mengusulkan sebuah metrik adaptif aritmatik yang efisien untuk kompresi gambar berdasarkan model campuran. Untuk setiap blok gambar, model yang diusulkan mendefinisikan campuran distribusi yang diperoleh dari blok yang berdekatan. Hasil percobaan kami membuktikan bahwa efisiensi kompresi citra dari metode yang diusulkan melebihi encoders aritmatika konvensional dan standar kompresi komersil lossless terbaru, JPEG-LS, masing - masing lebih dari $21 \%$ dan $31 \%$ [7].

Mengacu pada penjelasan diatas, maka penelitian ini bermaksud untuk merealisasikan sebuah codec citra medis berbasis fractal dengan mengujikan kinerjanya pada teknik entropy coding Adaptive Huffman dan Arithmetic yang bertujuan untuk mendapatkan nilai kompresi terbaik pada data hasil kompresi citra, sehingga dapat digunakan pada bagian Radiologi Rumah Sakit Umum Mangusada Badung. Sasaran dalam penelitian ini adalah untuk mendapatkan sebuah teknik pengkodean yang menghasilkan kinerja PSNR yang baik serta mampu memberikan rasio kompresi setinggi mungkin dengan kualitas citra rekonstruksi yang tetap terjaga dan waktu proses yang tidak lama.

\section{TINJAUAN PUSTAKA}

\section{A. Citra Digital}

Terdapat dua jenis citra, yakni citra kontinyu dan citra diskrit. Sistem optik yang menerima sinyal analog dapat menghasilkan citra kontinyu, sedangkan pada citra diskrit merupakan digitalisasi citra kontinyu. Pengolahan citra dengan mempresentasikan secara numerik fungsi nilai kontinyu menjadi nilai diskrit, inilah yang disebut digitalisasi dimana akan mendapatkan nilai citra digital [8]. Citra juga merupakan suatu gambaran, atau kemiripan, dari suatu objek sebagai media untuk menyimpan data secara visual, contohnya gambar dua dimensi yang digunakan untuk menyimpan sebuah peristiwa. Citra digital memiliki dimensi ukuran panjang lebar atau $\mathrm{N}$ x $\mathrm{M}$ yang pada umumnya dituliskan menggunakan matriks yang berukuran $\mathrm{N}$ sebagai baris dan M sebagai kolom.

Dibawah ini merupakan persamaan matriksnya :

$$
\boldsymbol{f}(\boldsymbol{x}, \boldsymbol{y}) \approx\left[\begin{array}{cccc}
f(0,0) & f(0,1) & \cdots & f(0, M) \\
f(1,0) & f(1,1) & \cdots & f(1, M) \\
\vdots & \vdots & \vdots & \vdots \\
f(N-1,0) & f(N-1,1) & & f(N-1),(M-1)
\end{array}\right]
$$

Pada indeks baris $(x)$ dan indeks kolom $(y)$ menerangkan titik koordinat dalam citra tersebut, sebaliknya pada $f(x, y)$ menyatakan derajat keabuan pada titik $(x, y)$. Setiap bagian pada citra digital disebut dengan image element, atau piksel [9]. Sebagai contoh, terdapat citra dengan ukuran $256 \times 256$ piksel maka citra tersebut disampaikan ulang secara numerik menggunakan matrik yang terdiri dari 256 baris dan 256 kolom. Adapun contoh matriks citra adalah sebagai berikut :

$\left[\begin{array}{cccccc}0 & 134 & 145 & 145 & \cdots & 321 \\ 0 & 167 & 201 & 201 & \cdots & 197 \\ 220 & 187 & 189 & 189 & \cdots & 120 \\ \vdots & \vdots & \vdots & \vdots & \vdots & \vdots \\ \vdots & \vdots & \vdots & \vdots & \vdots & \vdots \\ 221 & 219 & 210 & 210 & \cdots & 156\end{array}\right]$

Kolom koordinat $(0,0)$ pada piksel pertama memiliki nilai 
intensitas nol menyatakan bahwa warna piksel tersebut hitam. Piksel dengan nilai mendekati nol cenderung berwarna kehitaman, sedangkan piksel dengan nilai mendekati 255 cenderung berwarna putih. Berdasarkan besar kecilnya nilai satu piksel yang mewakili nilai keabuan, citra dapat dikelompokan menjadi tiga jenis, yakni:

a. Citra biner yang nilai tiap pikselnya hanya terdiri dari kombinasi dua bit, yakni bit 1 dan 0 (hanya mampu menampilkan warna hitam dan putih).

b. Citra RGB (Red Green Blue) adalah citra berwana, dimana tiap piksel memiliki jumlah bit untuk merepresentasikan warna spesifik yang merupakan kombinasi tiga warna dasar, yakni merah, hijau, dan biru.

c. Citra grayscale yang nilai setiap pikselnya adalah kombinasi dari 8 bit bilangan biner untuk menampilkan warna hitam, putih, dan abu-abu.

\section{B. Citra Medis}

Teknik atau proses untuk mendapatkan gambar tubuh khususnya gambar bagian dalam tubuh manusia untuk keperluan medis disebut dengan Citra Medis. Citra Medis dilakukan diantaranya untuk mengetahui bentuk dan fungsi pada bagian tubuh, adanya racun-racun tertentu dan penurunan metabolisme dalam tubuh [10].

Tujuan Citra Medis sebagai berikut :

1. Untuk mengembangkan metode komputasi dan Algoritma untuk menganalisis dan menghitung data biomedis.

2. Menjalin kerjasama dengan peneliti NIH di pusat penelitian lain dalam menerapkan analisis informasi dan visualisasi untuk masalah biomedis.

3. Untuk mengembangkan alat (baik hardware ataupun software) yang memiliki kemampuan untuk menganalisa data biomedis serta mendukung penemuan dan kemajuan biomedis. Beberapa Citra Medis yang saat ini digunakan adalah sebagai berikut :

1. Computed Tomography (CT - Scan).

2. X-ray

3. Ultrasonography (USG)

4. Endoscopy

5. Magnetic Resonance Imaging (MRI)

\section{Fractal}

Benda geometris yang kasar pada segala skala, dan terlihat dapat "dibagi-bagi" dengan cara yang radikal disebut dengan fractal. Istilah fractal berasal dari kata Latin fractus yang artinya "patah", "tidak teratur", atau "rusak", teori ini dibuat pada tahun 1975 oleh Benoît Mandelbrot. Cabang matematika yang mempelajari sifat-sifat dan perilaku fractal disebut dengan Geometri Fractal. Fractal mampu mendeskripsikan dengan menggunakan geometri klasik yang cukup banyak digunakan pada sains, teknologi, dan seni karya komputer untuk memudahkan situasi yang sulit. Objek-objek Fractal memiliki dimensi pecahan yang bisa juga disebut dengan fractional dimension. Metode yang umum digunakan untuk menghitung dimensi dari objek fraktal adalah metode penghitungan kotak yang juga disebut dengan box counting yang dapat dinyatakan sebagai berikut [11].

I Made Aditya Virgiawan : Codec Citra Berbasis Fractal......

$$
D(s)=\frac{\log (N(s))}{\log (s)}
$$

dengan $\mathrm{N}(\mathrm{s})$ menyatakan banyaknya kotak berukuran $\mathrm{s}$ yang berisi informasi (pixel) objek, dan $\mathrm{D}(\mathrm{s})$ adalah dimensi fractal objek dengan kotak berukuran s. Langkah-langkah metode penghitungan kotak adalah sebagai berikut. Pertama, citra dibagi kedalam kotak-kotak dengan ukuran s. Kedua, hitung banyaknya kotak $\mathrm{N}(\mathrm{s})$ yang dibutuhkan melingkupi suatu objek. Nilai $\mathrm{N}(\mathrm{s})$ sangat tergantung pada s. Nilai $\mathrm{s}$ berubah dari 1 sampai $2 \mathrm{k}$, dengan $\mathrm{k}=0,1,2, \ldots$ dan seterusnya, dan $2 \mathrm{k}$ tidak boleh lebih besar dari ukuran citra. Bila citra berukuran $2 \mathrm{~m} \times 2 \mathrm{~m}$, maka nilai $\mathrm{k}$ akan berhenti sampai $\mathrm{m}$. Ketiga, hitung $\mathrm{D}(\mathrm{s})$ dengan persamaan (2.31). Langkah terakhir adalah membuat garis lurus (regresi linier) berdasarkan nilai-nilai $\log (\mathrm{N}(\mathrm{s})$ ) (sebagai sumbu y) dan nilainilai $\log (\mathrm{s})($ sumbu $\mathrm{x})$. Kemiringan (slope) dari garis lurus tersebut merupakan dimensi fractal dari suatu objek.

\section{Pengkodean Adaptive Huffman}

Metode yang berkembang secara aktif meng-update dua Huffman tree identik di Encoder dan Decoder disebut dengan Adaptive Coding. Suatu binary tree dimana node-nya mempunyai counter frekuensi (kemunculan) memiliki sibling property jika tiap node (kecuali root) saat scanning (breadthfirst-right-to-left tree) membangkitkan list dari node-node yang mempunyai harga counter frekuensi yang tidak meningkat disebut dengan teknik Adaptive Huffman Coding. Keuntungan lain dari sistem ini adalah kebutuhan akan lewatnya data, data akan lewat hanya sekali (tanpa table statistic). Tentu saja, metode one-pass tidak akan menarik apabila jumlah bit yang ditransmisikan lebih besar dari metode twopass. Namun, performa dari metode ini, dalam ruang lingkup jumlah bit yang ditransmisikan, dapat lebih baik daripada static Huffman coding [12].

Pada Adaptive Huffman coding :

1. Tree mencakup counter untuk tiap simbol, dan suatu counter di-update setiap input simbol yang sesuai dikodekan.

2. Memastikan sibling property dipertahankan agar dapat menjamin Huffman tree yang sedang dibangun tetap Huffman tree.

3. Jika sibling property dilanggar, tree harus direstrukturisasi untuk mengembalikan property ini.

4. Algoritma mempunyai link list nodes berisi node-node dari tree yang disusun menurut scanning breadth-firstright-to-left tree.

5. Blok $\mathrm{i}$ adalah bagian dari list dimana tiap node mempunyai frekuensi i, dan node pertama dari tiap blok disebut leader.

6. Terlebih dahulu kita harus mengetahui frekuensi pada tiap-tiap karakter sebelum dilakukannya proses pengkodean menggunakan Metode SHC.

7. SHC merupakan metode yang dikembangkan dari metode AHC, yang dibuat secara dinamis saat membaca

p-ISSN:1693 - 2951; e-ISSN: 2503-2372 
data melalui proses penghitungan frekuensi karakter dan pembuatan huffman tree.

8. Pada informasi yang bersifat statis, akan tepat bila kita menggunakan Algoritma Huffman, sebaliknya pada informasi multimedia yang datanya belum dapat dipastikan kedatangannya (audio dan video streaming) Adaptive Huffman dapat dipergunakan.

9. Metode SHC maupun AHC merupakan kompresi yang bersifat loseless.

\section{E. Pengkodean Arithmetic}

Awal tahun 1960 Abramson dan Peter Elias untuk pertama kalinya mengembangkan metode Arithmetic Coding. Memberikan setiap simbol sebuah range atau interval $[0 ; 1]$, dimana pada setiap range dibagi dalam beberapa subrange yang ukurannya sebanding dengan probabilitas itu merupakan gagasan utama pada Arithmetic Coding. Semakin tinggi probabilitas yang dimiliki oleh suatu simbol maka semakin tinggi pula range yang diberikan terhadap simbol tersebut [13].

Arithmetic coding menggantikan satu deretan simbol input dengan sebuah bilangan floating point. Semakin panjang dan semakin kompleks pesan yang dikodekan maka semakin banyak bit yang diperlukan untuk keperluan tersebut. Satu angka yang lebih kecil dari satu dan lebih besar atau sama dengan 0 merupakan output dari Arithmetic Coding. Tiap simbol yang akan di encode diberikan satu set probabilitas untuk dapat menghasilkan angka output.

Setelah menentukan range dan probabilitas, dilakukan tahapan encoding kode-kode untuk mendapatkan nilai output angka floating point itu berada [14]. Algoritma proses kompresi menggunakan pengkodean Arithmetic adalah sebagai berikut :

a. Cari peluang dari tiap karakter pada teks yang akan dikodekan

b. Tetapkan nilai low_interval $(0)=0$ high_interval $(0)=1$ range_interval $(0)=1$

c. while not EOF (fin), baca karakter ke-i do

low $(i)=$ low_interval $_{(i-1)}+$ range_interval $(i-1)$

*low_range_symbol

$\operatorname{high}(i)=$ low_interval $_{(i-1)}+$ range_interval $(i-1)$

*high_range_symbol

low_interval $(i)=\operatorname{low}(i)$

high_interval $(i)=\operatorname{high}(i)$

range_interval $(i)=\operatorname{high}(i) \operatorname{low}(i)$

return

Dibutuhkan algoritma dekompresi yang merupakan kebalikan dari algoritma kompresi agar dapat mengembalikan data citra terkompresi menjadi data citra aslinya. Dibawah ini merupakan algoritma dekompresi citra dengan metode Arithmetic:

a. $\operatorname{output}(0)=$ nilai hasil kompresi

b. while output $(i) !=0$ do

$$
\text { output }(i)=\frac{(\text { output }(i-1)-\text { low range symbol })}{(\text { high range symbol-low range symbol })}
$$

c. return

\section{METODE PENELITIAN}

Rancangan penelitian ini menggunakan tahapan seperti pada Gambar 1.

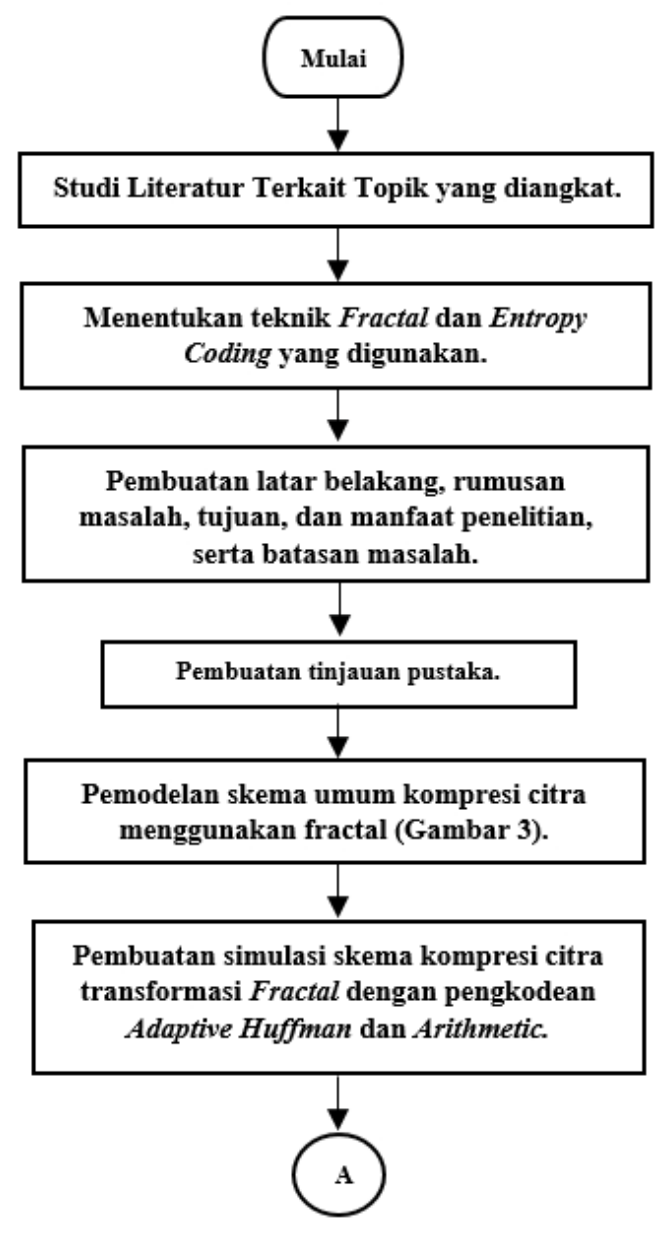

Gambar 1. Tahapan Pertama Penelitian

Langkah-langkah yang dilakukan untuk menyelesaikan penelitian ini sesuai pada Gambar 1, diawali dengan studi literatur terkait kompresi citra. Dari studi literatur tersebut, didapat permasalahan mengenai perlu dilakukannya kompresi pada citra khususnya pada citra medis sehingga dalam penelitian ini dirancang sebuah skema kompresi citra medis. Berdasar pada penelitian-penelitian sebelumnya, maka ditentukan teknik transformasi citra yang digunakan adalah Fractal dengan teknik entropy coding Adaptive Huffman dan Arithmetic. Berikutnya merupakan pembuatan latar belakang, rumusan masalah, tujuan penelitian, manfaat penelitian, serta batasan masalah yang diikuti dengan pembuatan tinjauan pustaka. Tahap selanjutnya, membuat pemodelan skema umum kompresi citra menggunakan fractal untuk mendapatkan algoritma pembuatan simulasi pada MatLab. Algoritma tersebut dikembangkan dan diterjemahkan ke dalam program MatLab sehingga diperoleh sebuah simulasi kompresi citra medis secara utuh sesuai dengan skema yang dirancang.

Tahapan kedua pada penelitian ini seperti pada Gambar 2. 


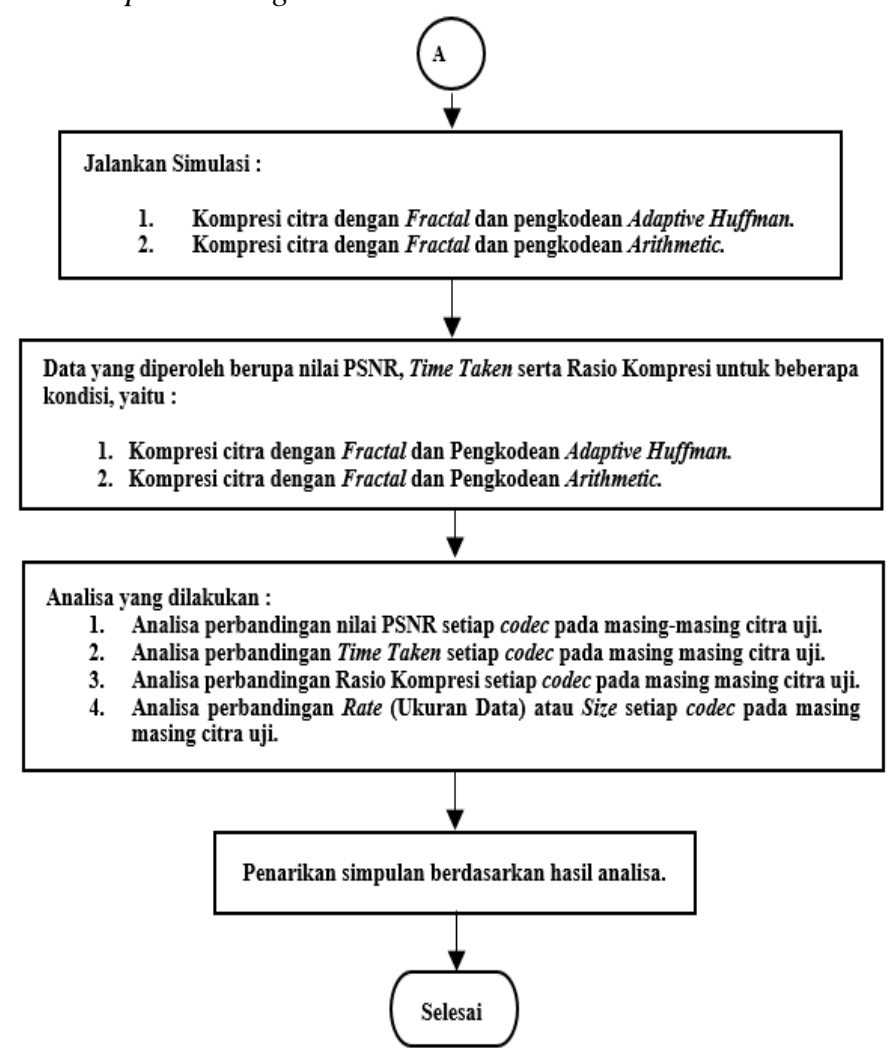

Gambar 2. Tahapan kedua Penelitian

Berdasarkan Gambar 2, terdapat dua metode pengujian simulasi skema kompresi citra medis, yakni menggunakan fractal dengan dengan teknik pengkodean Adaptive Huffman, dan menggunakan fractal dengan teknik pengkodean Arithmetic. Dari dua metode pengujian tersebut, masingmasing akan menghasilkan data nilai PSNR, Time Taken dan rasio kompresi pada setiap citra yang kemudian akan dianalisa mengenai perbandingan nilai PSNR, Time Taken dan rasio kompresi setiap codec pada masing-masing citra uji.

Berdasarkan pada Proses

F. Skema Umum Kompresi Citra

Proses kompresi citra menggunakan Transformasi Fractal secara umum ditunjukan pada Gambar 3

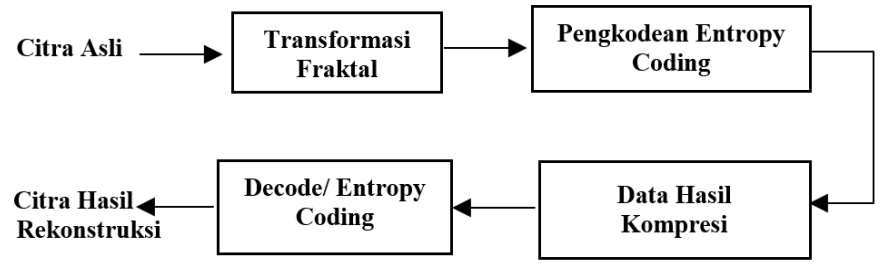

Gambar 3. Skema Umum Kompresi Citra

Kompresi diawali dengan menginputkan citra asli, kemudian dipindai dengan teknik scanning agar dapat ditampilkan dalam bentuk matriks yang mewakili nilai derajat keabuan tiap piksel. Matriks tersebut ditransformasi menggunakan fractal dengan dua jenis pengkodean entropy, yakni Adaptive Huffman dan Arithmetic. Dari proses filterisasi tersebut, dihasilkan sebuah matriks transformasi. Matriks hasil kuantisasi dikodekan menggunakan entropy coding sehingga representasi data yang baru memiliki ukuran lebih kecil dibandingkan dengan data citra awal. Untuk tahap dekompresi, inputan berupa data hasil kompresi yang kemudian didekodekan serta direkonstruksi menggunakan transformasi fractal.

G. Alur Kompresi Citra Menggunakan Teknik Fractal dengan Pengkodean Adaptive Huffman, dan Arithmetic.

Pada Gambar 4 terlihat bahwa proses kompresi diawali dengan menginputkan citra awal.

User menginputkan data citra awal, selanjutnya data citra awal masuk kedalam proses transformasi fractal, kemudian data yang sudah dihasilkan akan dikompresi dengan 2 teknik entropy coding, yaitu Adaptive Huffman dan Arithmetic, dimana dalam proses kompresi pada data citra awal didapatkan pola citra yang telah teridentifikasi, kemudian dipindai dengan teknik scanning agar dapat ditampilkan dalam bentuk matriks yang mewakili nilai derajat keabuan tiap piksel. Matriks tersebut ditransformasi menggunakan fractal dengan dua jenis pengkodean entropy, yakni Adaptive Huffman dan Arithmetic. Setelah dilakukan proses pada masing-masing pengkodean entropy, yang menghasilkan nilai PSNR dan time taken, Rasio Kompresi, serta Rate (ukuran data) atau size lalu dilakukan analisa perbandingan terhadap nilai-nilai tersebut dan kemudian dilakukan pengujian dengan citra awal dan citra hasil kompresi. 


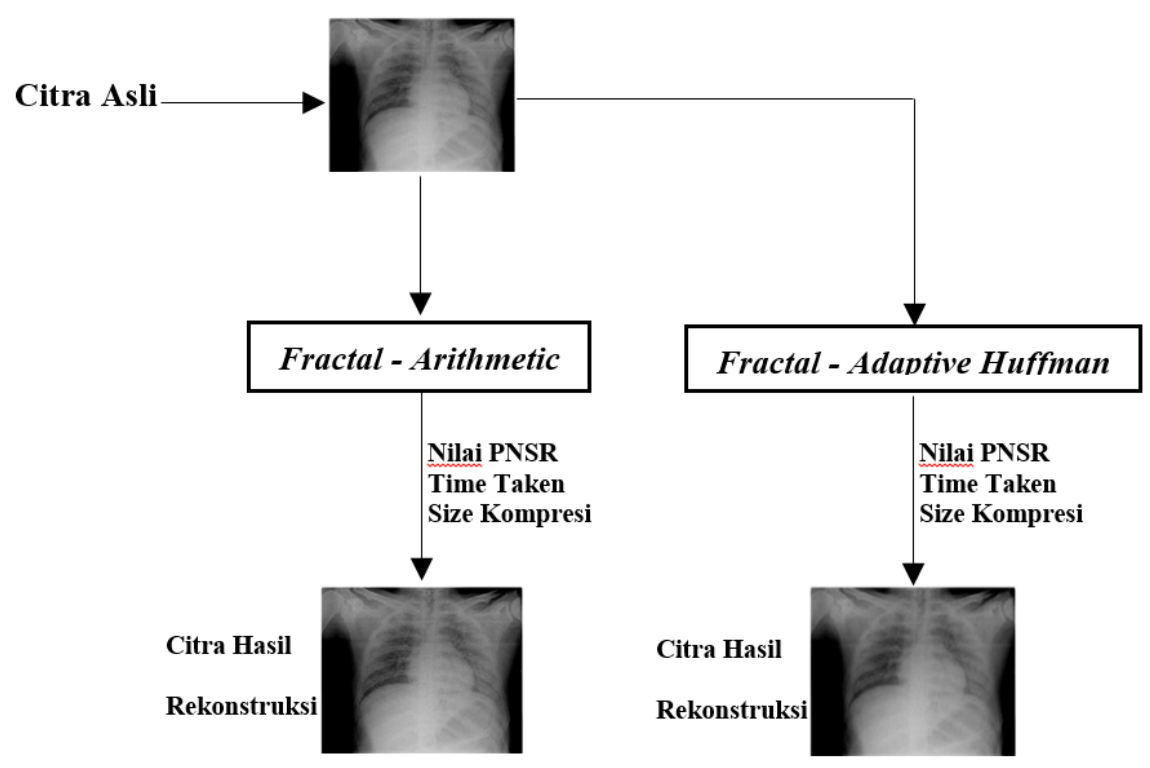

Gambar 4. Alur Kompresi Citra Medis

\section{HASIL DAN PEMBAHASAN}

Hasil dari penelitian yang dilakukan, dapat dilihat melalui implementasi dari rancangan sistem yang diusulkan dan analisa dari hasil implementasi sistem dilihat dari Nilai PSNR, Time Taken, Rasio Kompresi, dan Rate (ukuran data) atau size yang dihasilkan dengan menggunakan transformasi fractal dan entropy coding Adaptive Huffman dan Arithmetic.

Tampilan aplikasi GUI (Grafic User Interface) hasil implementasi matlab bisa dilihat pada gambar 5 :

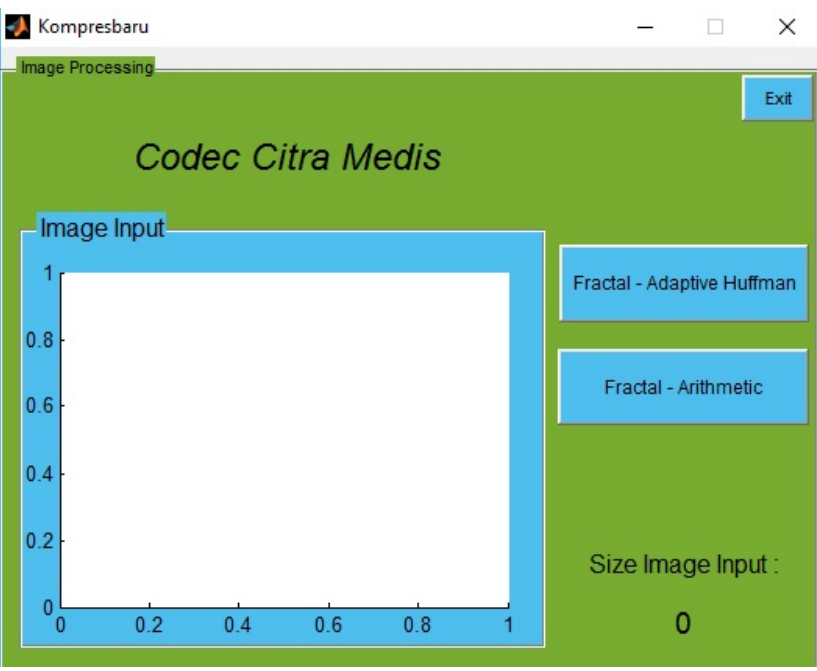

Gambar 5. Tampilan Aplikasi GUI (Grafic User Interface)

Pengujian pada penelitian ini dilakukan dengan mengkompresi lima belas buah citra uji berupa citra medis grayscale yang berdimensi $256 \times 256$ piksel. Semua data citra uji ini merupakan citra hasil $X$-Ray.
H. Evaluasi Hasil Pengujian

Dalam pengujian ini digunakan 2 codec citra berbeda untuk dianalisis kinerja kompresinya.

Codec citra yang digunakan yakni :

1. Implementasi sistem menggunakan fractal dan entropy coding adaptive huffman.

2. Implementasi sistem menggunakan fractal dan entropy coding arithmetic.

Tabel dibawah ini menunjukkan hasil pengujian kualitas kompresi citra setiap codec citra pada masing-masing citra uji, adapun yang dihasilkan dari setiap proses pengujian yakni, nilai PSNR, nilai kompresi dan nilai time taken, sebagai berikut :

TABEL 1

Hasil Pengujian Kualitas Kompresi pada Citra Uji

\begin{tabular}{|c|c|c|c|c|c|}
\hline \multirow{2}{*}{$\begin{array}{c}\text { No } \\
\text { Citra }\end{array}$} & \multirow[t]{2}{*}{ Codec Citra } & \multirow{2}{*}{$\begin{array}{l}\text { Time } \\
\text { Taken } \\
\text { (s) }\end{array}$} & \multicolumn{2}{|c|}{ Kompresi } & \multirow{2}{*}{$\begin{array}{l}\text { PSNR } \\
(\mathrm{dB})\end{array}$} \\
\hline & & & $\begin{array}{l}\text { Rate } \\
(\mathrm{kB})\end{array}$ & $\begin{array}{c}\text { Rasio } \\
(\%)\end{array}$ & \\
\hline \multirow[t]{2}{*}{$\begin{array}{l}\text { Citra } \\
\text { Uji } 1\end{array}$} & $\begin{array}{l}\text { Fractal - Adaptive } \\
\text { Huffman }\end{array}$ & 107,33 & 5,68 & 8,63 & 18,01 \\
\hline & Fractal - Arithmetic & 34,18 & 2,92 & 9,29 & 34,95 \\
\hline \multirow[t]{2}{*}{$\begin{array}{l}\text { Citra } \\
\text { Uji } 2\end{array}$} & $\begin{array}{l}\text { Fractal - Adaptive } \\
\text { Huffman }\end{array}$ & 114,76 & 7,90 & 8,44 & 16,94 \\
\hline & Fractal-Arithmetic & 111,71 & 5,64 & 8,89 & 31,88 \\
\hline \multirow[t]{2}{*}{$\begin{array}{l}\text { Citra } \\
\text { Uji } 3\end{array}$} & $\begin{array}{l}\text { Fractal - Adaptive } \\
\text { Huffman }\end{array}$ & 131,13 & 6,46 & 8,56 & 9,42 \\
\hline & Fractal-Arithmetic & 83,81 & 4,77 & 8,94 & 34,56 \\
\hline \multirow[t]{2}{*}{$\begin{array}{l}\text { Citra } \\
\text { Uji } 4\end{array}$} & $\begin{array}{l}\text { Fractal - Adaptive } \\
\text { Huffman }\end{array}$ & 115,33 & 5,89 & 8,55 & 16,45 \\
\hline & Fractal-Arithmetic & 58,73 & 3,89 & 9,04 & 34,43 \\
\hline \multirow[t]{2}{*}{$\begin{array}{l}\text { Citra } \\
\text { Uji } 5\end{array}$} & $\begin{array}{l}\text { Fractal - Adaptive } \\
\text { Huffman }\end{array}$ & 134,08 & 6,55 & 8,53 & 6,34 \\
\hline & Fractal-Arithmetic & 96,38 & 5,15 & 8,84 & 34,66 \\
\hline \multirow[t]{2}{*}{$\begin{array}{l}\text { Citra } \\
\text { Uji } 6\end{array}$} & $\begin{array}{l}\text { Fractal - Adaptive } \\
\text { Huffman }\end{array}$ & 112,24 & 7,02 & 8,41 & 13,57 \\
\hline & Fractal-Arithmetic & 107,21 & 5,88 & 8,67 & 34,28 \\
\hline \multirow[t]{2}{*}{$\begin{array}{l}\text { Citra } \\
\text { Uji } 7\end{array}$} & $\begin{array}{l}\text { Fractal - Adaptive } \\
\text { Huffman }\end{array}$ & 117,55 & 5,70 & 8,56 & 15,47 \\
\hline & Fractal-Arithmetic & 37,57 & 3,16 & 9,20 & 34,59 \\
\hline
\end{tabular}

I Made Aditya Virgiawan : Codec Citra Medis Berbasis........ 


\begin{tabular}{|c|c|c|c|c|c|}
\hline \multirow[t]{2}{*}{$\begin{array}{l}\text { Citra } \\
\text { Uji } 8\end{array}$} & $\begin{array}{l}\text { Fractal - Adaptive } \\
\text { Huffman }\end{array}$ & 119,72 & 7,00 & 8,46 & 12,97 \\
\hline & Fractal-Arithmetic & 76,04 & 4,91 & 8,92 & 33,93 \\
\hline \multirow[t]{2}{*}{$\begin{array}{l}\text { Citra } \\
\text { Uji } 9\end{array}$} & $\begin{array}{l}\text { Fractal - Adaptive } \\
\text { Huffman }\end{array}$ & 131,25 & 7,96 & 8,38 & 11,65 \\
\hline & Fractal-Arithmetic & 119,81 & 6,37 & 8,70 & 33,76 \\
\hline \multirow[t]{2}{*}{$\begin{array}{c}\text { Citra } \\
\text { Uji } 10\end{array}$} & $\begin{array}{l}\text { Fractal - Adaptive } \\
\text { Huffman }\end{array}$ & 118,51 & 5,19 & 8,65 & 16,78 \\
\hline & Fractal - Arithmetic & 36,08 & 2,81 & 9,27 & 34,91 \\
\hline \multirow[t]{2}{*}{$\begin{array}{c}\text { Citra } \\
\text { Uji } 11\end{array}$} & $\begin{array}{l}\text { Fractal - Adaptive } \\
\text { Huffman }\end{array}$ & 103,53 & 7,36 & 8,46 & 22,68 \\
\hline & Fractal-Arithmetic & 95,71 & 5,03 & 8,95 & 34,47 \\
\hline \multirow[t]{2}{*}{$\begin{array}{c}\text { Citra } \\
\text { Uji } 12\end{array}$} & $\begin{array}{l}\text { Fractal - Adaptive } \\
\text { Huffman }\end{array}$ & 129,54 & 6,25 & 8,56 & 9,36 \\
\hline & Fractal-Arithmetic & 69,63 & 4,15 & 9,04 & 34,13 \\
\hline \multirow[t]{2}{*}{$\begin{array}{c}\text { Citra } \\
\text { Uji } 13\end{array}$} & $\begin{array}{l}\text { Fractal - Adaptive } \\
\text { Huffman }\end{array}$ & 106,52 & 6,99 & 8,42 & 21,33 \\
\hline & Fractal-Arithmetic & 101,34 & 5,02 & 8,87 & 34,54 \\
\hline \multirow[t]{2}{*}{$\begin{array}{c}\text { Citra } \\
\text { Uji } 14\end{array}$} & $\begin{array}{l}\text { Fractal - Adaptive } \\
\text { Huffman }\end{array}$ & 104,53 & 6,78 & 8,53 & 26,21 \\
\hline & Fractal-Arithmetic & 68,27 & 4,15 & 9,10 & 34,64 \\
\hline \multirow[t]{2}{*}{$\begin{array}{c}\text { Citra } \\
\text { Uji } 15\end{array}$} & $\begin{array}{l}\text { Fractal - Adaptive } \\
\text { Huffman }\end{array}$ & 105,49 & 6,09 & 8,50 & 21,47 \\
\hline & Fractal-Arithmetic & 66,59 & 3,91 & 9,04 & 34,34 \\
\hline
\end{tabular}

Perbandingan nilai PSNR yang sudah dihasilkan melalui proses kompresi pada masing-masing data citra uji. Berdasarkan data yang diperoleh dari lima belas data citra uji yang sudah dilakukan didalam penelitian ini, maka dapat dilihat perbandingan nilai PSNR pada setiap codec citra medis pada Gambar 6.

Gambar 6 menunjukkan perbandingan nilai PSNR adalah sebagai berikut :

a. Nilai PSNR tertinggi terlihat pada penggunaan Codec Fractal-Arithmetic disetiap citra uji. Nilai PSNR pada Codec Fractal-Arithmetic tersebut memiliki nilai PSNR diatas $30 \mathrm{~dB}$.

b. Nilai PSNR pada citra uji 1 pada Codec FractalArithmetic memiliki nilai PSNR tertinggi yakni 34,95 dB.

c. Nilai PSNR terendah dari setiap citra uji adalah dengan menggunakan Codec Fractal-Adaptive Huffman, disini terlihat pada citra uji 5 menghasilkan Nilai PSNR terendah yakni $6,34 \mathrm{~dB}$.

I. Analisa Perbandingan Nilai PSNR

PSNR dihitung untuk mengukur perbedaan antara citra semula dengan citra hasil kompresi, adapun nilai PSNR didapatkan pada program MatLab dengan melakukan penghitungan menggunakan rumus dapat dituliskan sebagai berikut :

$P S N R=20 \times \log _{10}\left(\frac{b}{M S E}\right)$

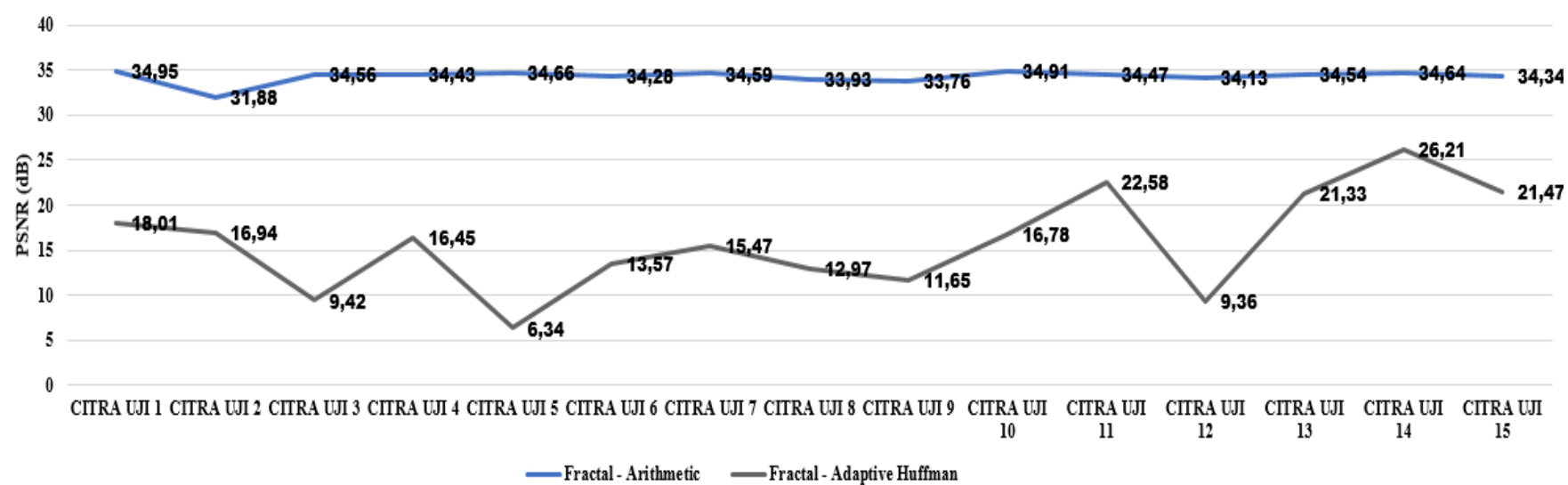

Gambar 6. Grafik Perbandingan Nilai PSNR Citra Uji

I Made Aditya Virgiawan : Codec Citra Berbasis Fractal...... 


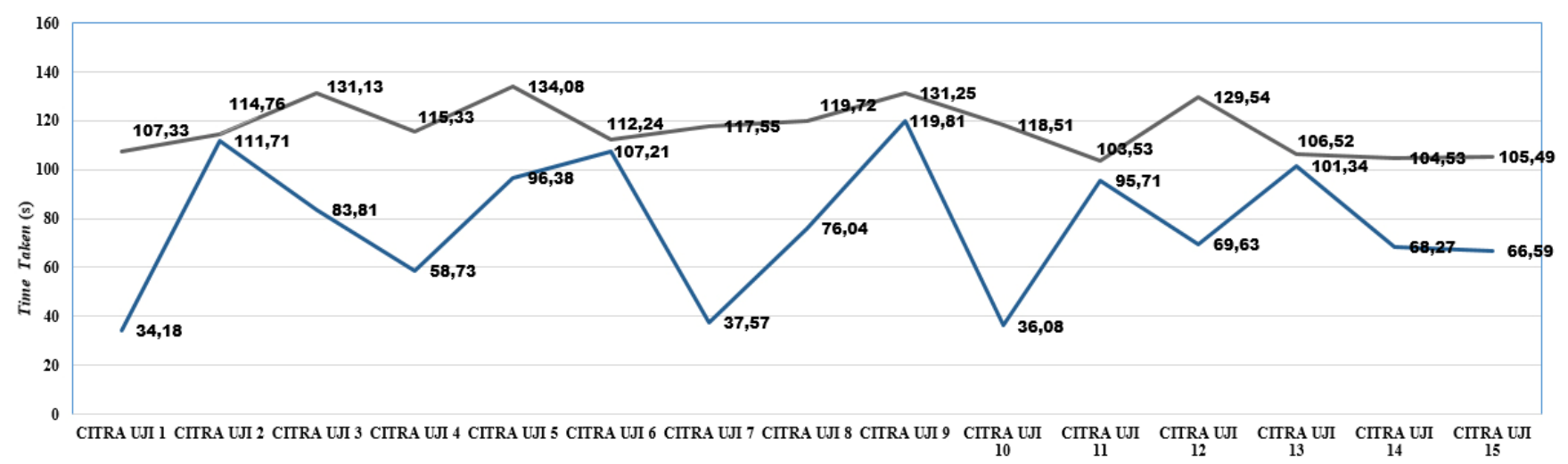

—Fractal - Arithmetic —Fractal - Adaptive Huffman

Gambar 7. Grafik Perbandingan Time Taken Citra Uji

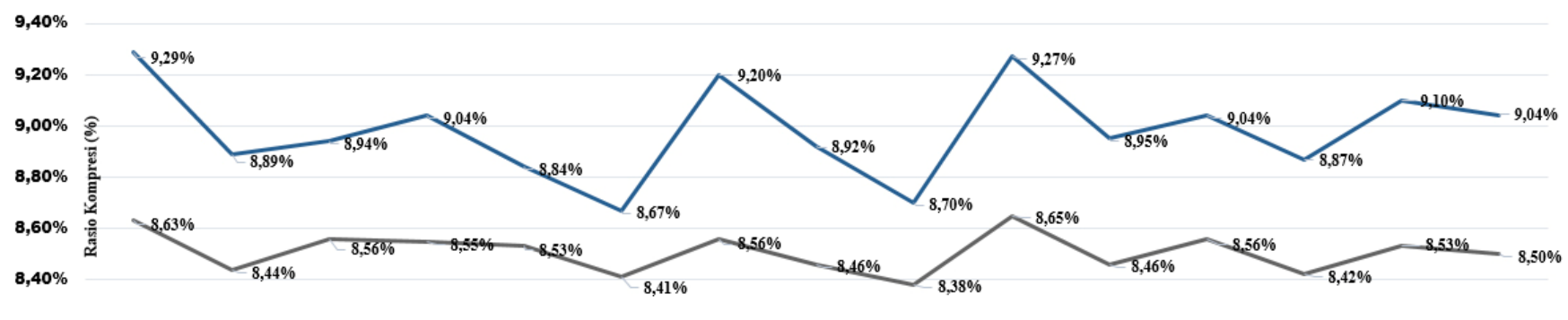

$8,20 \%$

$8,00 \%$

$\mathbf{7 , 8 0 \%}$

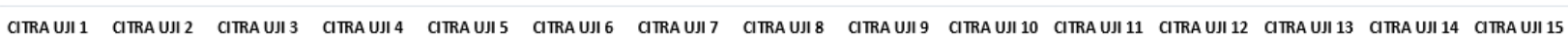
-Fractal - Arithmetic —Fractal - Adaptive Huffman

Gambar 8. Grafik Perbandingan Rasio Kompresi Citra Uji

\section{J. Analisa Perbandingan Time Taken}

Nilai time taken didapatkan pada saat melakukan proses kompresi citra, yang dihitung dari awal proses kompresi berjalan, sampai menghasilkan data citra yang sudah didekompresi.

Berdasarkan data yang diperoleh dari lima belas data citra uji yang sudah dilakukan didalam penelitian ini, dalam setiap proses pengujian masing masing citra uji mendapatkan Waktu Tempuh/Proses (Time Taken) compresion nya, maka dapat dilihat perbandingan nilai Waktu Tempuh (Time Taken) pada setiap codec citra yang sudah diujikan pada setiap citra uji pada Gambar 7.

Gambar 7 menunjukkan perbandingan rata-rata waktu tempuh (Time Taken) pada setiap codec citra dan setiap citra uji yang dilakukan. Analisis detail terhadap Gambar 7 adalah sebagai berikut :

a. Waktu tempuh (Time Taken) sebuah codec melakukan kompresi pada citra uji 2, 6, dan 13 rata-rata waktu tempuh dalam melakukan kompresi tidak terlalu berbeda dari setiap codec. b. Waktu tempuh (Time Taken) tercepat dihasilkan pada citra uji 1 menggunakan Codec Fractal-Arithmetic yakni $34,18 \mathrm{~s}$.

c. Waktu tempuh (Time Taken) terlama dihasilkan pada citra uji 5 menggunakan Codec Fractal-Arithmetic yakni 134,08 s (2 menit 14 detik).

d. Secara keseluruhan, pada Codec Fractal-Arithmetic menghasilkan waktu tempuh (Time Taken) yang lebih cepat jika dibandingkan dengan Codec Fractal-Adaptive Huffman, hal tersebut bisa dilihat pada hasil keseluruhan citra uji.

K. Analisa Perbandingan Rasio Kompresi

Rasio kompresi dihitung untuk mengukur perbandingan ukuran file citra sebelum dan sesudah dikompresi. Nilai rasio kompresi yang besar akan menjadi target dalam suatu teknik kompresi citra, namun besarnya nilai rasio kompresi harus diikuti dengan kualitas citra, adapun persamaan matematis rasio kompresi dapat dituliskan sebagai berikut :

Rasio Kompresi $(\%)=\frac{(O-C)}{O} \times 10$ 
Setiap proses pengujian masing masing citra uji menghasilkan nilai rasio kompresi yang berbeda - beda, maka dapat dilihat perbandingan rasio kompresi pada setiap codec citra yang sudah diujikan pada setiap citra medis dapat dilihat pada Gambar 8.

Gambar 8 menunjukan perbandingan nilai rasio kompresi pada setiap codec citra dan setiap citra uji yang sudah dilakukan. Analisis detail terhadap Gambar 5 adalah sebagai berikut :

a. Rasio kompresi dari setiap codec terlihat rata-rata perbandingan rasio kompresi setiap image dibawah $10 \%$.

b. Rasio kompresi paling rendah adalah pada Codec Fractal-Adaptive Huffman pada citra uji 9 yaitu sebesar $8,38 \%$.

c. Rasio yang paling tinggi terlihat pada citra uji 1 dengan menggunakan Codec Fractal-Arithmetic yakni mencapai nilai rasio kompresi 9,29\%.

d. Perbedaan teknik pengkodean yang digunakan akan berpengaruh pada nilai rasio kompresi yang dihasilkan, karena pengkodean Adaptive Huffman dan Arithmetic bersifat lossless.

L. Analisa Perbandingan Citra Asli dan Citra Hasil Kompresi

Berdasarkan data yang diperoleh dari lima belas data citra uji yang sudah dilakukan didalam penelitian ini, dalam setiap proses pengujian masing masing citra uji menghasilkan gambar citra uji yang memiliki nilai PSNR, Time Taken, dan Rasio Kompresi yang berbeda - beda.

Maka dapat dilihat perbandingan kualitas gambar yang dihasilkan pada citra uji 1, yang secara kasat mata terlihat seperti tabel dibawah ini :

TABEL 2

Perbandingan Gambar Citra Asli dan Citra Hasil Kompresi Citra Uji 1

\begin{tabular}{|c|c|c|c|c|c|}
\hline No & $\begin{array}{c}\text { Codec } \\
\text { Citra }\end{array}$ & Citra Asli & Citra Hasil & Size Asli & $\begin{array}{c}\text { Size } \\
\text { Hasil }\end{array}$ \\
\hline Citra & $\begin{array}{l}\text { Fractal- } \\
\text { Arithmetic }\end{array}$ & & - & $41,57 \mathrm{kB}$ & $2,92 \mathrm{kB}$ \\
\cline { 2 - 6 } & $\begin{array}{l}\text { Fractal- } \\
\text { Adaptive } \\
\text { Huffman }\end{array}$ & & - & $41,57 \mathrm{kB}$ & $5,68 \mathrm{kB}$ \\
\hline
\end{tabular}

Citra Uji 1 pada tabel 2 terlihat dari tabel tersebut bahwa, size citra hasil kompresi yang dihasilkan pada Codec FractalArithmetic menghasilkan size yang lebih kecil yakni $2,92 \mathrm{kB}$ jika dibandingkan dengan Codec Fractal-Adaptive Huffman yang menghasilkan size $5,68 \mathrm{kB}$, dimana dari data size citra awal sebelum dilakukan kompresi citra yakni 41,57 kB.

Analisa perbandingan citra asli dan citra hasil kompresi secara keseluruhan menghasilkan nilai size citra kompresi pada codec citra fractal-arithmetic yang jauh lebih kecil jika dibandingkan dengan codec citra fractal-adaptive huffman.

\section{Kesimpulan}

Berdasarkan hasil pengujian dan analisa yang telah dilakukan pada kompresi citra medis menggunakan fractal dengan teknik pengkodean Adaptive Huffman dan Arithmetic, maka dapat disimpulkan sebagai berikut :

a. Nilai PSNR menggunakan Codec Fractal-Adaptive Huffman lebih rendah dibandingkan dengan menggunakan Codec Fractal-Arithmetic yakni rata-rata diatas 9,63 dB sampai dengan $26,21 \mathrm{~dB}$ atau dibawah 30 $\mathrm{dB}$, berbeda halnya dengan menggunakan Codec Fractal-Arithmetic rata-rata nilai PSNR diatas $30 \mathrm{~dB}$ yakni rata-rata 32,53 dB sampai dengan 34,95 dB.

b. Berdasarkan 15 data citra uji menunjukkan waktu tempuh (time taken) pemrosesan dalam 1 gambar pada Codec Fractal-Arithmetic lebih unggul dibandingkan dengan Codec Fractal-Adaptive Huffman yakni waktu kompresi tercepat adalah pada citra uji 2 dengan waktu 34,18 s, sedangkan untuk Codec Fractal-Adaptive Huffman menghasilkan rata-rata waktu diatas 100 second atau sekitar 1 menit 40 detik.

c. Codec Fractal-Arithmetic menghasilkan nilai rasio kompresi yang lebih tinggi jika dibandingkan dengan Codec Fractal-Adaptive Huffman. Rasio kompresi yang paling tinggi terlihat pada citra uji 2 dengan menggunakan Codec Fractal-Arithmetic yakni mencapai 9,29\%, sedangkan rasio kompresi yang paling rendah pada Codec Fractal-Adaptive Huffman pada citra uji 1 yaitu sebesar $8,28 \%$. Perbedaan teknik pengkodean yang digunakan lebih berpengaruh pada jumlah bit setiap citra yang dihasilkan karena pengkodean Adaptive Huffman dan Arithmetic bersifat lossless.

d. Codec Fractal-Arithmetic menghasilkan ukuran data atau size yang lebih kecil dibandingkan dengan Codec Fractal-Adaptive Huffman, karena memiliki perbedaan dasar algoritma pengkodean. Adaptive Huffman mengkodekan setiap koefisien ke dalam bit yang panjangnya tergantung dari probabilitas kemunculan koefisien tersebut, sedangkan Arithmetic hanya mengkodekan output terakhir dari hasil komputasi aritmatika yang digunakan sebagai data hasil kompresi.

\section{REFERENS}

[1] Garnita. 2016. "Kompresi Citra Medis dengan Menggunakan Discrete Wavelet Transform dengan Pengkodean Huffman dan Arithmetic".

[2] Ari Widagdo, 2012. "Implementasi Algoritma Huffman pada Kompresi Citra"

[3] Budiman. 2012. "Kompresi Citra Medis Menggunakan Metode Wavelet". Agri-tek Volume 14 Nomor 2

[4] Rasha Adel Ibrahim. 2015. "Fractal Image Compression". International Journal of Advanced Research (2016), Volume 4, Issue 7, 322-326

[5] Veenadevi.S.V \& A.G.Ananth. 2012. "Fractal Image Compression Using Quadtree Decomposition and Huffman Coding”. Signal \& Image Processing : An International Journal (SIPIJ) Vol.3, No.2, India.

[6] Putu Ayu Indira Savitri. 2016. "Digital Medical Image Compression Algorithm Using Adaptive Huffman Coding and Graph Based Quantization Based on IWT-SVD”. Fourth International Conference on Information and Communication Technologies (ICoICT). IEEE 
[7] Atef Masmoudi. 2014 "An Effiecient Adaptive Arithmetic Coding for Block-Based Lossless Image Compression Using Mixture Models". IEEE

[8] Santi Ika Murpratiwi. 2018. "Pemilihan Algoritma Kompresi Optimal Untuk Citra Digital Bitmap". MITE

[9] Made Oka Widyantara. 2018. "Pemampatan Citra Pas Foto Dengan Menggunakan Algoritma Kompresi Joint-Photograpic Experts Group (JPEG) dan Principal Component Analysis (PCA)".

[10] Cahyo Hendi Prastyo. 2013. "Kompresi Citra dengan Metode Arithmatic Coding dalam Kawasan Entropy Coding".

[11] Ketut Gede Darma Putra. 2009. "Sistem Verifikasi Biometrika Telapak Tangan dengan Metode Dimensi Fraktal dan Lacunarity”. MITE
[12] Sianipar, Rismon, H, WJ., Sri Muliani, 2013. "Kompresi Citra Digital Berbasis Wavelet Tinjauan PSNR dan Laju Bit", Jurnal Informatika, Vol. 4, No. 2, pp. $81-87$.

[13] Shoko Nakatsuka. 2013. “An Efficient Lossless Data Compression Method based on Exponential-Golomb Coding for Biomedical Information and its Implementation using ASIP Technology". IEEE

[14] Truncation Coding (AMBTC) dan Prediction-Error Expansion (PEE)".

[15] Joarder, R., Crundwell, N., 2009." Chest X-Ray in Clinical Practice". Springer Science \& Business Media. New York 